\title{
AN EDUCATIONAL APPLICATION FOR A PRODUCT DESIGN AND ENGINEERING SYSTEMS USING INTEGRATED CONCEPTUAL MODELS
}

\section{UNA APLICACIÓN EDUCACIONAL PARA EL DISEÑO DE PRODUCTOS Y SISTEMAS DE INGENIERÍA UTILIZANDO MODELOS CONCEPTUALES INTEGRADOS}

\author{
Bernabé Hernandis Ortuño ${ }^{1} \quad$ Juan Carlos Briede Westermeyer ${ }^{2}$ \\ Recibido 8 de octubre de 2007, aceptado 14 de octubre de 2009 \\ Received: October 8, 2007 Accepted: October 14, 2009
}

\begin{abstract}
RESUMEN
El presente artículo describe el uso y la aplicación de una nueva metodología desarrollada para el diseño conceptual de nuevos productos que refuerza aquellos aspectos innovadores del proceso de diseño fomentando el desarrollo creativo. Es un modelo dinámico basado en el pensamiento cíclico que mantiene las prescripciones impuestas o decididas libremente por el diseñador. Contempla amplios grados de desagregación y desarrollo en su definición y permite registrar la información durante todo el proceso. Su aplicación y posterior análisis para el desarrollo conceptual de productos como su uso en investigación permite abordar los aspectos fundamentales que contempla el diseño y transferirlos como características implícitas en éste. También se muestra una de las prácticas docentes en que se ha utilizado el diseño en ingeniería, como así también los resultados obtenidos. El modelo se aplicó a dos grupos de alumnos con experiencia en diseño de productos. Este modelo ha supuesto una reducción de tiempos que mejoró los resultados comparativos de años anteriores. La utilización del modelo gestiona el conocimiento de manera separada y utiliza el dibujo como síntesis representativa, basada en los modelos teóricos que estructuran los atributos teóricos del producto según los objetivos planteados. Es un modelo que sirve de guía, pues determina totalmente las pautas de trabajo generando mayores beneficios, ya que además de guiar al alumno/diseñador en su aplicación implica una manera organizada y estructurada de recogida de información facilitando su posterior presentación y razonamiento del problema propuesto.
\end{abstract}

Palabras clave: Diseño, ingeniería, sistemas, sistémica, innovación, modelo, educación, productos, diseño conceptual.

\begin{abstract}
This article describes the use and application of a new methodology that has been developed for the conceptual design of new products, which emphasizes those innovating characteristics in design processes, thus fostering creative development. This is a dynamic model based on a cyclic thought that keeps the prescriptions that have been applied or decided without restrain by the designer. It comprises a broad range of disjointing and development degrees regarding their definition, while making it possible to record information during the whole process. Its application and further analysis for product conceptual development, such as their use in research works makes it feasible to undertake fundamental issues with respect to design and to have them transferred as the design own characteristics. Likewise, a teaching practice where the design has been used in engineering is shown, along with the outcomes that have been achieved. This model was applied in two groups of students who had some experience in product design. The model has assumed timing decrease, which in turn brought about results when compared with previous years. The use of this model manages knowledge on a separate fashion while using drawings as a representative synthesis, based on theoretical models that make up the product theoretical features according to the objectives that had been established. This model can be used as a guideline, since it completely states working patterns and, therefore, providing greater benefits, since in besides guiding students/designers in its application, it also implies an organized and structured manner of information gathering, thus making the suggested product further introduction and reasoning easier.
\end{abstract}

Keywords: Design, engineering, systems, systemic, innovation, model, education, products, conceptual design.

1 Departamento de Ingeniería Gráfica. Universidad Politécnica de Valencia. C P: 46022. Valencia, España. E-mail: bhernand@ degi.upv.es

2 Departamento de Arte y Tecnologías del Diseño. Universidad del Bío-Bío. C P: 4050231. Concepción, Chile. E-mail: jbriede@ubiobio.cl 


\section{INTRODUCTION}

The design of new products must respond to a series of varying requirements imposed by others - including the global market, the consumer, and the production department. A great deal of information must be processed when developing new products, and in this area information technologies are being combined with concurrent and collaborative approaches to engineering [1-2]. Product development is handled as a simultaneous and interactive activity from the beginning of the process, and now includes aspects that were previously resolved in prior phases.

This is the definition of a new paradigm in product development; concentrating different strategic decisions regarding the new product in the initial design phases.

This information and knowledge management [3] must be handled efficiently, so that the creative process results in real and innovative solutions.

Product life management (PLM) [4] is seen as a model by companies attempting to optimise product engineering over the whole life of a product: from the initial steps such as conceptual design - to withdrawal at the end of the useful life of a product.

In this context, our proposed focus using systemic methodology [5] enables information to be registered from the first creative thought and throughout the various design stages - and as a result this information becomes part of the knowledge management process. This innovative methodological focus is based on a model (the modelling phase) [6-7], that establishes the separation of the fundamental design factors.

This division enables lateral thought because each product aspect must be independently and simultaneously analyzed. This requires a new approach and supposes a change in the way problems are focused - as well as a change in the way designers and engineers are taught.

In this article, we will briefly comment on the model structure, and its teaching application as a learning model.

\section{Design and systemic}

If we apply these considerations to product design we can see that we are referring to a structure based on systems and multiple relations. The analysis of the influencing factors in conceptual design, as well as their values according to the proposed objectives and how we can incorporate these into conceptual design, opens new possibilities for designers. This process can be handled with an adequate knowledge management system - from the beginning of the design task to the end solution. Nowadays, one of the challenges posed is how to manage the various design phases and control the associated information. It must be remembered that most design work contains complexity levels requiring flexible information control processes.

Systemic methodologies enable the consideration of these multiple factors - and the effects caused by diverse alternatives.

Currently, much of the investigative work is based on the initial phases of the design process, and the subsequent use of the information generated for successive works [8].

Our work is based on the modelling of the factors that integrate design - with the aim of optimally managing the information and quickening product development by taking advantage of the accumulated experience in each development.

An analysis of sub-systems and common relationships between types of products demonstrates how an initial definition of the design and common elements can be made for a range of products - independently of their shape characteristics [9].

Now, if we actually refer to the systemic approach as a methodological principle to be applied in product design, we might find out that there are some advanced methodologies having a high degree of systematization, such as the Hubka \& Eder [10] and Pahl \& Beitz [11] statements, which in turn are focused on defining an engineering design. Its approach has been stated with the purpose of undertaking the design of complex systems, as well as devices (technical systems), which means knowledge about engineering, calculus and strength, thus centering in that kind of products. Likewise, there is a similitude or a parallel condition with respect to the initial theoretical stages in a series of statements regarding the design process development.

The proposal that has herein been stated assumes theoretical definition assumes the theoretical definition by means of a systemic disjointing of the initial variables. Such disjoining makes up the product definition out of a system in turn made up by three basic sub-systems, which by using relationship nodes among each other, make it possible to generate a dynamic system that is sensitive to the criteria and variables that have been introduced. 


\section{Creative thinking}

We must take into account the thoughts that lead us to the maximum expression of creativity, and remember to plan for the management of knowledge so that generated information can be re-used. This is a creative and development optimization process.

As the result of the union between the lineal [12], lateral [13] and cyclical thinking models, new system models can be established. This is the main theme of this article.

Creative thinking [14] involves changing normal thinking patterns, also known as programmed thought [15]. It refers to breaking the thinking barriers - both logical and emotional. It creates a space where we can think about a problem by changing perspective and creating new original ideas.

Lateral thinking also enables us to break thought patterns, and consequently helps create brilliant and original solutions for problems and new opportunities.

Paul E. Plsek [16] poses a creative thinking model guided by the thinker, where creative processes require the impulsive implementation of ideas. He argues that it is not enough to just imagine new devices; we must work to make them reality. Systemic design models act as a support for the development and implementation of creative design: as shown in Plesk's model phase IV.

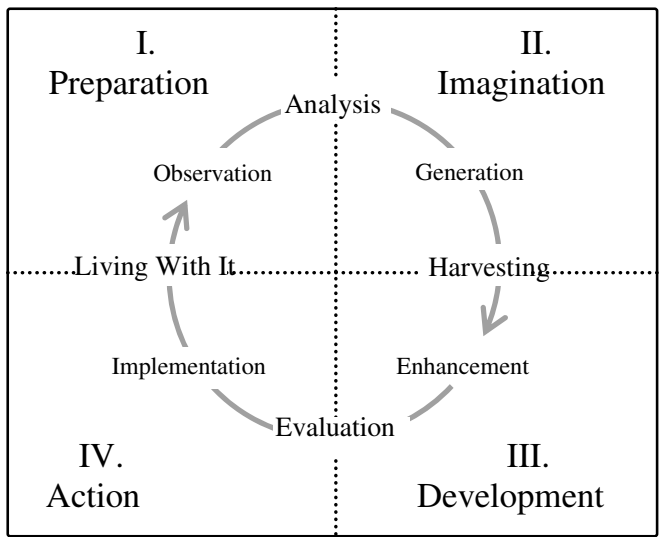

Figure 1. Directed creativity cycle: A synthesis model of the creative process.

Figure 1 shows a model of creative process synthesis and the distinctive phases it passes through. These phases provide structure and help clarify the relationship between the mental and physical state of the individual - from preparation with 'observation' until the idea is specified through 'implementation'. Creativity is the synthesis of ideas and concepts created through a radical reconstruction and reassociation. Innovation is the tangible implementation of creativity.

Creativity, from the engineering point of view, may nearly be the same as the generation of ideas, while innovation is the application of these ideas to products. The relationship between creativity and innovation suggested by W. Li, J. Tsai, S. Tseng, and I.F. Young. [17] establishes a parallel with the industrial design process.

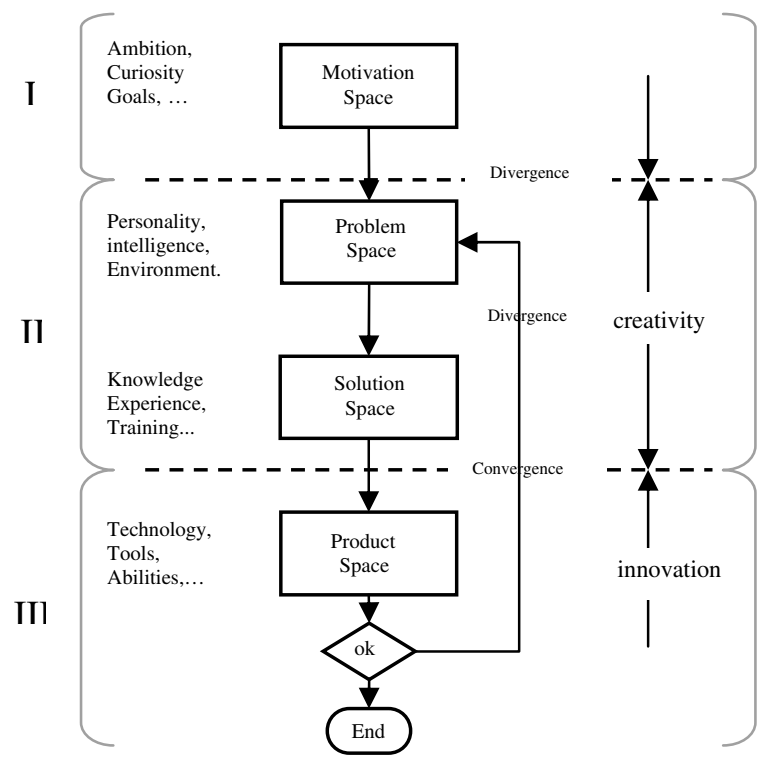

Figure 2. The stages of creativity and innovation in the design process. Diagram based on W. Li, J. Tsai, S. Tseng, and I.F. Young [17].

Figure 2 shows the engineering design process through a previous phase of strategic definition - before reaching the conceptual design phase (creativity) and the subsequent phase where solutions appearing in the detailed design phase (innovation) are applied and developed. According to this implementation scheme, the innovatory role of the proposal depends on translation of the creatives elements from the problem/solution space to the product space.

\section{Lateral and cyclical thinking}

If we take into account the creative process with the objective of promoting innovation, we should consider different thinking patterns.

Lateral thinking raised by E. De Bono, breaks the pattern of habitual thought using methods that may seem at first illogical. The aim is to stimulate the generation of new ideas. 
Every innovative process is accompanied by a creative process. It is here where several approaches differ. According to E De Bono "Vertical thinking is analytic and moves only if there is a direction for it to move; lateral thinking is provocative and moves in order to create a direction." [18].
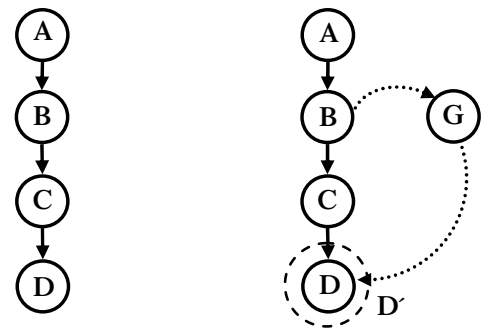

Figure 3. Diagram based on De Bono.

The comparative diagrams in Figure 3 show the process of sequential thinking on the left; and lateral thinking on the right. The lateral approach jumps the sequence to include a new idea and so obtains a new result.

As Bono says: "Vertical thought is based on a sequence of ideas; lateral thought hops along."

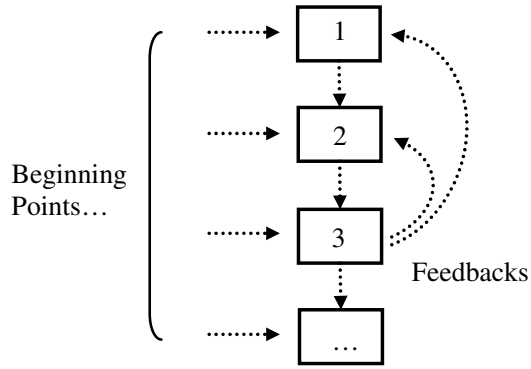

Figure 4. Diagram based on the concurrent model.

Figure 4 shows two characteristics of the concurrent model that establish a number of elements as starting points for developing a problem (number of elements $=$ number of starting points). Feedback is not necessarily sequential and is shown as a mechanism to redefine and reconsider other aspects of the problem.

Using systemic models for product development, creates a lateral thinking exercise which supposes the division of the product being designed into three subsystems: form, function, and ergonomics. This division enables the individual development and evaluation of each aspect, and also enables a simultaneous means to study the attributes of the product. So, it is useful to continue describing new proposals through a conceptual design.
By being able to jump steps, solutions may be found from any step of the methodogical sequence. Moreover, the application of a model systemic that list all the sub-systems included in the model - through the use of relation variables - means global solutions can be obtained. However, a peculiar characteristic, such as finding as many starting points as elements, would be reflected in the model (Figure 5). This means that the actual starting point is irrelevant in the application of the methodological process (concurrent design model); and this, in turn, means that errors can be more easily detected and corrected.

The model also implies a cyclical approach; it means that it has a feed-back approach in relation to the fundamental factors integrating the design.

\section{Cyclical thinking}

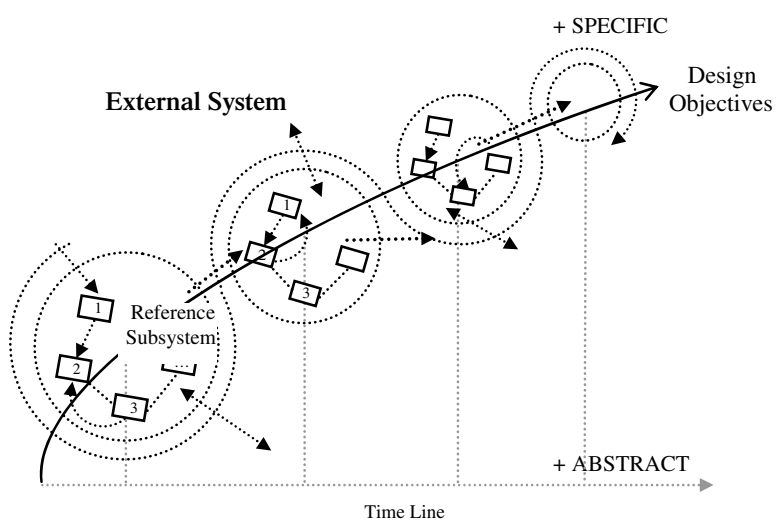

Figure 5. Cyclical thinking in the concurrent model.

Figure 5 shows the Concurrent Model along with its development in time, through a cycle-based thought, in turn guided by objectives that make it possible the achievement of consensus based and global definition of the product, by analyzing and defining those feedback factors and their relation.

Christiaans [19] claimed in his study that: 'the more time an individual invests in the definition and understanding of a problem, and consequently using his own references to create conceptual structures, the better prepared the individual is'.

This conceptual structure is implemented thanks to the implementation of a systemic model described below. 


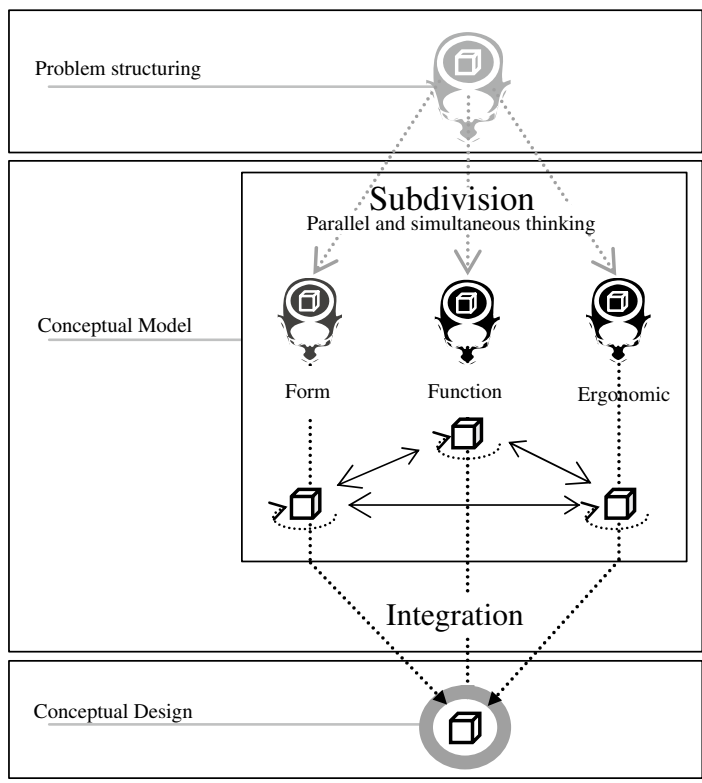

Figure 6. Systemic model for new product innovation and design (model of concurrent design, 2003).

Figure 6 shows the use of the model as a mental mechanism to stimulate thought in three phases: I Conventional Thought - receiving information; II Subdivision - simultaneous and parallel division of design factors and definition, analysis, and decision; III Integration - the values and fundamental aspects of product design are weighted in a conceptual proposal which leads to a design concept.

\section{Systemic Model}

Many of the problems detected in recent decades regarding the complexity of data management no longer exist. This is thanks to the evolution of information technology, which is able to control and resolve difficult problems, not only from the point of view of the mathematical models used, but also because information technology provides the processes and common tools used by designers.

Product analysis, with the aim of determining its integrating factors, has been traditionally been made in a rather intuitive way, from the first inklings of an idea to the termination of the task.

Vitrubio made a division of the design characteristics in $32 \mathrm{BC}$, in terms of aesthetic, functionality and reuse. This was perhaps the first conscious division of the factors integrating design. In the last century, Mintzberg [20] discussed the field of form, and stated that the objective is to satisfy the aesthetic requirements of a product. In the same way, it is the aim of function to give technological aspects to a product; while ergonomics adapts the form and functional aspects to the user.

After studying many models we can infer recurrent patterns that anticipate new working methods. From this systemic perspective we analyze the subsystems integrating design, considering all the aspects and formulating an analysis that we consider appropriate for the concept modelled.

We propose an analysis based on decomposition of the fundamental subsystems of design: form, function, and ergonomics - into volumes, surfaces and contour limits. This division can incorporate all the values that integrate the design, enabling the construction of a conceptual model, formulated by objectives that can be generalized for any product analysis.

Cases are analysed where the application is studied and appropriate definitions regarding volume, area, and outline are observed. The advantage of this division appears in its incorporation into systemic models which, in turn, establish theoretical models with the desired abstraction level. This shows that the system can be applied to all cases.

With the development of systemic methods, especially in contributive design, we are able to choose the best response to the proposed objectives from the existing prescriptions and possibilities. This requires attributing characteristics to the product from a form, function, and ergonomic perspective. We aim to build concepts about the product when looking at the fundamental subsystems.

To accurately look at volume, area, and outlines, we need to differentiate between positive volumes which belong to an object's geometry, and negative volumes which define the geometrical considerations regarding normative restrictions, specifications, or particular considerations. These correspond to the environment, and are just as important as those attributed to the final physical shape of the product. These negative volumes belong to an immaterial world and are built from the geometries of use. The sum of the positive and negative geometries equals the 'design space', or design polyhedron from a geometrical point of view. Both define the external and internal factors that optimise the design objectives.

\section{IMPLEMENTATION OF CONCURRENT DESIGN MODEL IN DESIGN EDUCATION}

The normative model is taught in two parallel courses. The first course is entitled 'Leisure and Auto Mechanics' and is given in the school of Technical Design Engineering 
at the Polytechnic University of Valencia. The second course is called, 'Design Methodology', and is given in the $8^{\text {th }}$ version of the University Masters Course in Design, Management and Development of New Products (DIGD).

The model implementation stages were completed until the stage where the theoretical model was able to handle the conceptual design. The degree of separation and depth in the implementation of the model was set at two levels of difficulty - in relation to the level of student experience, and taking into account that the first group were design students while the second group were already design graduates. The task was to design a product up to the conceptual phase. This task was undertaken by teams of students varying between two and five members.

We will discuss the application of the model to conceptual design phase. This model is from a group of third-year students of Industrial Design and Technical Engineering from the Leisure and Auto Mechanics course 2006/7. The implementation of the model was adapted according to the availability and the experience of the students. The criteria resulted in a process developed in the following stages:

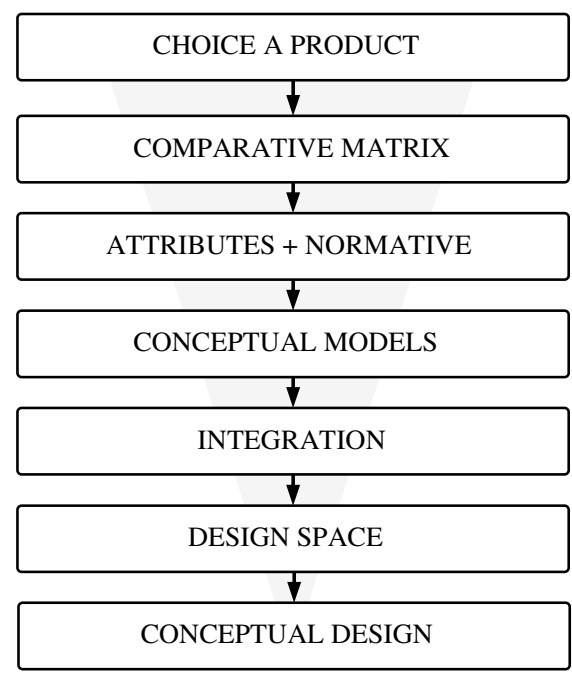

Figure 7. Steps in implementing the model.

Figure 7 shows a sequence of six steps and the tasks associated with each in an implementation process leading to a conceptual design.

The following steps were taken to implement the model phase corresponding to the concurrent design:

\section{Choose a Product}

Various sources were consulted to determine what kind of product to design: opinion polls (user necessities), previous designer knowledge (experiences and tastes), necessity or opportunity detection, and customer demand (requirements). Also, the objectives of the product must be defined. This is fundamental as it serves as a guideline for all of the subsequent process.

All of the steps inside the different phases are movable; meaning that they can be improved and changed, by analysis and feed-back.

\section{Comparative Matrix}

In this market study, all the products with similar characteristics to the chosen product are grouped together. The product characteristics are analysed separately establishing advantages (A) and disadvantages (D) from a form, functional, and ergonomic point of view for each point. See Figure 9. Such analysis of formal, functional and ergonometric characteristics in a disjointing manner makes it possible to have a preliminary approach toward both the systemic scope that has been suggested by the methodology and the theoretical practice that is implied by such cognitive process.

\begin{tabular}{|c|c|c|c|c|c|c|}
\hline & \multicolumn{2}{|c|}{ formal } & \multicolumn{2}{l|}{ functional } & \multicolumn{2}{l|}{ ergonomics } \\
\hline Product & A & D & A & D & A & D \\
\hline $\mathrm{N}^{\mathbf{0}} 1$ & $\ldots \ldots$ & $\ldots \ldots$ & $\ldots \ldots$ & $\ldots$ & $\ldots \ldots$ & $\ldots$ \\
\hline $\mathrm{N}^{\mathrm{o}} 2$ & $\ldots \ldots$ & $\ldots$ & $\ldots \ldots$ & $\ldots$. & $\ldots \ldots$ & $\ldots \ldots$ \\
\hline $\mathrm{N}^{\mathbf{0}} 3$ & $\ldots \ldots$ & $\ldots \ldots$ & $\ldots \ldots$ & $\ldots \ldots$ & $\ldots \ldots$ & $\ldots \ldots$ \\
\hline & $\ldots \ldots$ & $\ldots$ & $\ldots \ldots$ & $\ldots \ldots$ & $\ldots \ldots$ & $\ldots \ldots$ \\
\hline & $\ldots \ldots$ & $\ldots \ldots$ & $\ldots \ldots$ & $\ldots \ldots$ & $\ldots \ldots$ & $\ldots \ldots$ \\
\hline & $\ldots \ldots$ & $\ldots \ldots$ & $\ldots \ldots$ & $\ldots \ldots$ & $\ldots \ldots$ & $\ldots \ldots$ \\
\hline $\mathrm{N}^{\mathrm{o}} \mathrm{x}$ & $\ldots \ldots$ & $\ldots \ldots$ & $\ldots \ldots$ & $\ldots \ldots$ & $\ldots \ldots$ & $\ldots \ldots$ \\
\hline
\end{tabular}

advantages (A) and disadvantages (D)

Figure 8. Product comparative matrix. 
Figure 8 shows an analysis of the types of products using form, function, and ergonomic variables in a visual and textual description to help organisation and processing. It also shows the status of the Matrix technique that sorts and classifies product description on a systemic way, while emphasizing the formal, functional and ergonomic features in order to make further product analysis as well as the assortment of the characteristics the new product is expected to have easier.

\section{Attributes + Regulations}

Once the attributes of the product have been defined, other attributes not previously included in the competence matrix are considered, such as regulations which could condition or limit the proposal.

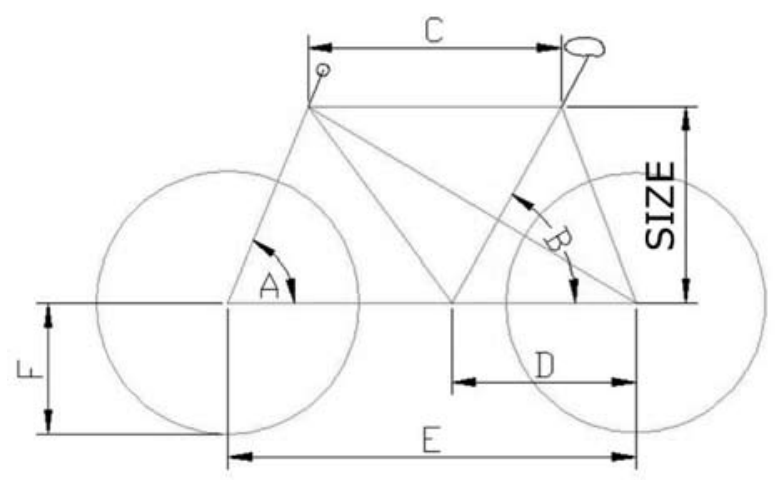

Figure 9. Standardised measurements for a mountain bike.

Figure 9 illustrates the measurements and relationships imposed by the design norms of a mountain bike. There are some standardized parametric relations that have to be complied by the time a frame for different kinds of mountain bikes is designed, together with the different sizes or dimensions (M, L, XL, XXL), depending on how tall users might be.

These are listed in a simplified modeling that relates and includes the attributes for each sub-system are added (form, function, and ergonomics).

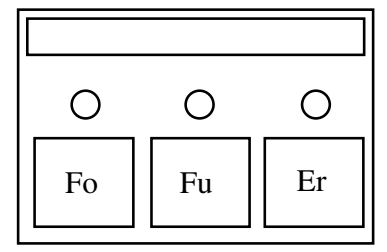

Figure 10. Concurrent Design Model.

Figure 10 displays the structure of the complete model, the the external system input variables, the sub-system objectives and the three integral sub-systems of design that are Form, Function and Ergonomics.

\section{Conceptual Models}

Once the attributes to be carried out by each subsystem have been incorporated, they are passed to the conceptual model implementation. This is the first attempt at converting the theoretical concepts to geometry. It is achieved by a theoretical diagram for each subsystem that is represented by an isometric cube, which simulates a space in which the different conceptual aspects, in terms as volume, surface and contour limits can be incorporated. This mental abstraction practice demands a great and complex effort; it also requires acute analysis as well as high relationship capabilities.

The following stage shall be the introduction of examples for the setting up of concept-based models by making use of the "A seat for urban transportation" project. Then, after conducting market research, product and its objectives definition, in addition to the definition and study of the comparative matrix, together with the fundamental features this product is expected to have, all these characteristics are converted into the geometries to be displayed in a physical context. Such geometries are both positive and negative: positive volume (+) such as back up, and negative volume (-), i.e., space: for instance, the necessary space to take hold of body concavity.

The implementation of the conceptual model is shown below using the 'Urban Transport Chair' project.

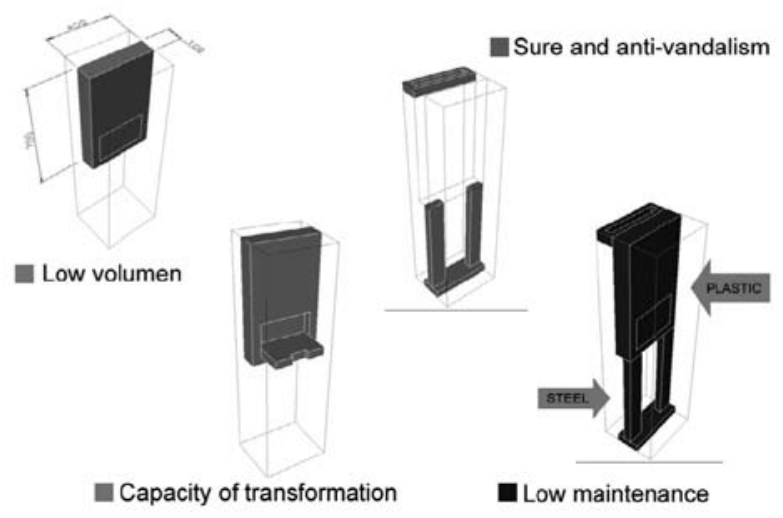

Figure 11. Functional Conceptual Model for "A Seat for Urban Transportation".

Figure 11 above shows the geometrical criteria that have been implemented for function definition, which are given through functional outline Volumes, Surfaces and Borders. Functional characteristics are geometry related. 
By doing so, the "anti-vandalistic and safe" concepts are converted into two volumes that shall provide structure and strength to the projected product.

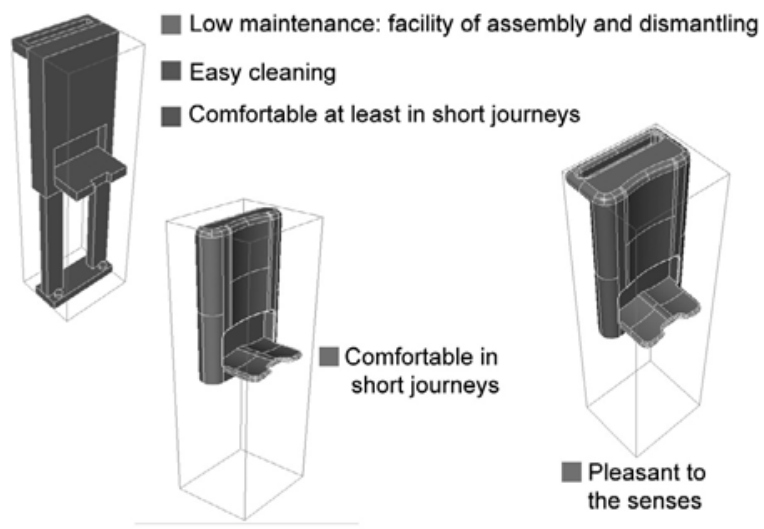

Figure 12.Ergonomic conceptual model for a 'Urban Transport Chair'.

Figure 12 shows the geometric criteria used for the definition of ergonomy - given as volumes, surfaces, and ergonomics contours.

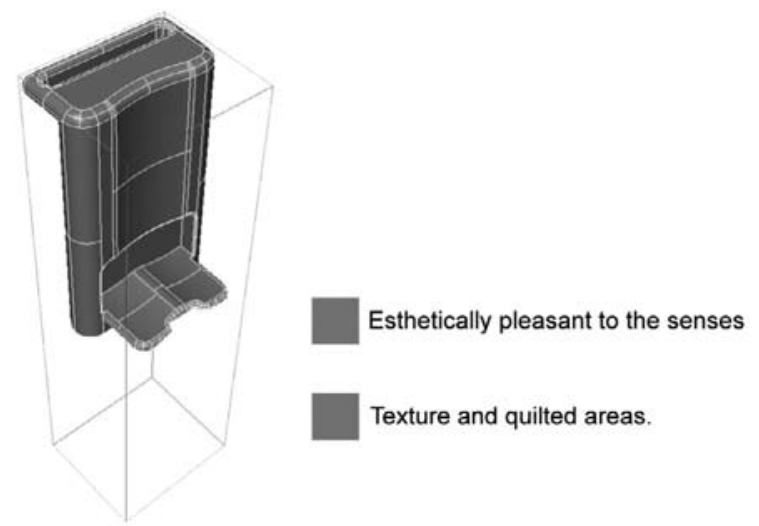

Figure 13. Form conceptual model for a 'Urban Transport Chair'.

Figure 13 shows the geometric criteria adopted for the definition of form - given as volumes, surfaces, and formal contours.

\section{Integration}

This is the moment where the different models that were independently generated (form, function and ergonomics) must be integrated. Every attribute and its consequences must be analyzed and valued (for example, detecting cases where two objectives are opposed), ranking the attributes in each case, and establishing unitary agreement.
It is important to highlight that because of the reasons mentioned earlier regarding the experience and the abstraction ability of the students, we chose a work flow in the modelling stage that had already inter-related the characteristics of each subsystem to the next subsystem, so suggesting a form, function, and ergonomic order for implementation. This made creating the model much easier because the variables in the model should be transferred to the next. Therefore, because of students' high level of expertise and abstraction competence, a modeling working sequence was chosen. Such sequence has inter-related the facets of each sub-system with the following one. This helped the integration, as each individual model began with the proposal made in the previous model.

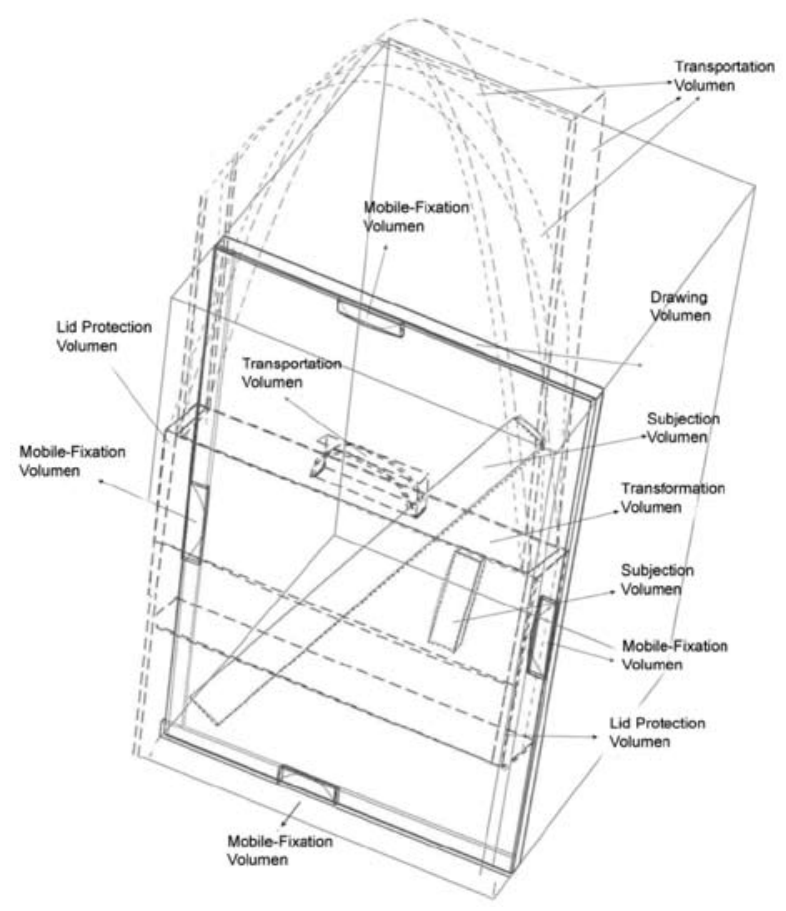

Figure 14. Integration of a conceptual model for a sketching transport and support system.

Figure 14 shows the integration of the geometric aspects of each sub-system into just one system. This process of synthesis and assessment does not consist in simply summarising results, but includes the integration and hierarchisation in a geometry that provides answers for the three sub-systems at product level.

On the other hand, with respect to the drawing support and transportation system, the fundamental volumes that are related to the product main features and that make its operating capacity possible have been defined. 


\section{Design Space}

This is the definition of a theoretical space where the different factors that compose the design process have to be modelled and studied. In this space, all the decisions made by the designer must be coherent.

\section{Conceptual Design}

In this proposal of conceptual design, the different design architectures included in the design space must be evaluated. Matrix methods, based on theory, or other methods chosen by the designer can be used. It is advisable to use a process capable of valuing complex solutions; and it must not be forgotten that complexity in most any design requires levels of decision not usually achievable from intuition.

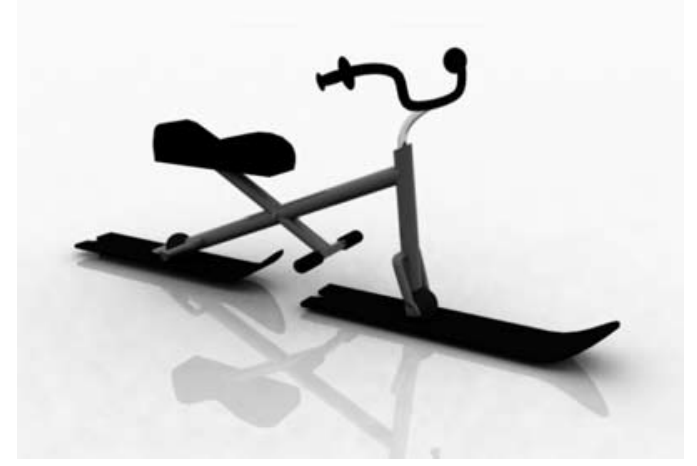

Figure 15. Conceptual design of a snow vehicle.

Figure 15 shows an example of a conceptual design illustrated with an image that reveals the structure and form characteristics of the proposed product. It is worth emphasising that at this stage the representation is used as a medium of visualisation and structurisation of the theoretical aspects previously defined [21].

\section{RESULTS}

The implementation of the model of concurrent design in teaching, and as a method of working, offers advantages, not only because it makes up a working guideline with specific steps to follow when designing, but also because it shortens the development of a conceptual design.

The implementation of the model is suggested as a sixstep process. Each of these steps is, in turn, divisible into activities with specific objectives. It can be shown that following the model has quickened the process and improved results compared with previous years.

\section{DISCUSSION}

Implementing this model as a work tool in design teaching is similar to establishing guidelines. It is worth remembering that the majority of students already had experience in product design. Undoubtedly, using the model offers advantages over traditional procedures. It offers a different approach that manages knowledge separately, and does not just use the design drawing as an immediate tool looking for a solution. The implementation of the model implies that these solutions respond in a specific way to the objectives of that specific moment, it may be guaranteed that the selected solution is not the first solution that came to mind. In many methods, it is automatically assumed that the result is based in designer experience, without reflecting on the analysis and depth level that concurrent design allows in its minimal conceptual expression.

\section{CONCLUSIONS}

The present model is a theoretical working tool that guides the designer in the process of product design, avoiding possible mental blocks or hesitations.

It analyses any product design in an ordered and structured way - locating the problems to be resolved and trying to clarify all possible implications in design fields. It also enables, unlike traditional design methods, the search for alternative and innovative designs, and optimizes customer or designer requirements from the beginning by fixing objectives.

This procedure is not free of inconveniences when compared to traditional methods. This is because it requires detailed work instead of the comparatively easy search for a bright idea, although keeping the contribution of the accumulated experience. Accordingly, this procedure requires greater dedication in its initial phase, but produces useful knowledge databases regarding the product model in the medium and long-term.

It has been verified that after the first application, students begin to acquire some experience and that it turns out to become quite useful for further developments because it establishes work guidelines. This represents a double advantage because these guidelines guide the student in an organized and structured way to use information, and this helps develop the posterior presentation and problem reasoning.

Another advantage is that a large part of the necessary modelling phase data for the initial design is repetitive and 
independent of the design in question. If this information is properly recorded, it shall become pretty useful for further designs.

On the other hand, when studying the different products, great coincidences were also found in the sub-systems, variables and, in general, regarding relationships among sub-systems. Because much of the information is repeated, this means that product-type models can be generated.

Such iterative processes in model application, as well as planned feed-back, prevent involuntary oversights.

The promotion of lateral and cyclical thinking requires encouraging innovative development. It is understood that the setting up of new innovating methodologies themselves make it possible to foster innovation, to contribute tangible benefits for the design of new products, as well as in those companies where they are developed.

\section{REFERENCES}

[1] F. Aguayo y V. Soltero. "Metodología del diseño industrial: un enfoque desde la ingeniería concurrente". Editorial Ra-Ma. Primera Edición, p. 631. Madrid, España. 2002.

[2] M. Contero, P. Company, C. Vila and N. Aleixos. "Product Data Quality and Collaborative Engineering". IEEE Computer Graphics and Applications. Vol. $22 \mathrm{~N}^{\circ} 3$, pp. 32-42. May/June 2002.

[3] E. Awad and H.M. Ghaziri. "Knowledge Management". Prentice Hall. United States Ed edition. $1^{\text {st }}$ Edition, p. 480. Englewood Cliffs. United States. 2003.

[4] M. Agustin, B. Hernandis and J. Briede. "PLM Lab: a Research and Test initiative involving Industry, Developers and University". International Technology, Education and Development Conference INTED. Valencia, España. 2007.

[5] L. Ferrer. "Del paradigma mecanicista de la ciencia al paradigma sistémico". SP-Universidad de Valencia, pp. 324-336. Valencia, España. 1998.

[6] B. Hernandis. "Diseño de nuevos productos. Una perspectiva sistémica". Cursos on-line. Formación Tutorizada a Distancia por Internet. Interf@d.
Servicio de Publicaciones Universidad Politécnica de Valencia. $1^{a}$ Edición, p. 289. Valencia, España. 1999.

[7] B. Hernandis "Desarrollo de una Metodología Sistémica para el Diseño de Productos Industriales". Tesis para optar al grado de doctor. Universidad Politécnica de Valencia, p. 359. Valencia, España. 2003.

[8] B. Hernandis. "Experiencias en torno al Diseño Sistémico de Productos". Primer Encuentro Interinstitucional de Diseño Industrial. Vol. 3, pp. 1-7. Mérida,Venezuela. 2005.

[9] B. Hernandis, M. Arribas, J. Bonmatí, J. Briede, M. Cabello, S. Llorens y A. Valero. "Análisis de los subsistemas integrantes del diseño". Publicación: Primeras Jornadas de Diseño de Productos. Editorial de los Andes. ISBN 980-11-0859-2, pp. 1-12. 2005.

[10] V. Hubka and W.E. Eder. "Design Science". Springer Verlag, Berlin, Heidelberg. 1996.

[11] G. Pahl and W. Beitz. "Engineering Design. A Systematic Approach”. Ed. Springer Verlag. 1996.

[12] A. Esteves. "Creación y proyecto. El método en diseño y otras artes". Editorial Institució Alfons el

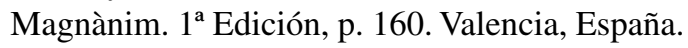
2001.

[13] E. De Bono. "El pensamiento lateral. Manual de creatividad". Ediciones Paidós Ibérica SA, pp. 48-49. Barcelona, España. 1974.

[14] B. Hernandis y M. Cabello "Creatividad, Innovación y desarrollo de nuevos productos". 2007. Fecha de consulta: 15 de Agosto 2006. URL: http://www. impivadisseny.es/disseny/index.php?option=com_c ontent $\&$ task $=$ view $\& i d=70 \&$ Itemid $=76$

[15] Mind Tools Ltd. "Programmed Thinking \& Lateral thinking". 2007. Fecha de consulta: 20 de diciembre 2006. URL: http://www.mind tools.com/pages/ article/newCT_00.htm

[16] P. Plsek. "Working Paper: Models for the Creative Process". Fecha de consulta: 20 diciembre 2006. URL: http://www.directed creativity.com/pages/ WPModels.html 
[17] W. Li, J. Tsai, S. Tseng and I.F. Young. "Generation of New Ideas for Product Functions and Engineering Innovation Practices: A Hands-on Project Model for Mechatronics Education”. Exploring Innovation in Education and Research iCEER-2005, pp. 1-9. Tainan, Taiwan. 2005.

[18] E. De Bono. "El pensamiento creativo: el poder del pensamiento lateral para la creación de nuevas ideas". Ediciones Paidós Ibérica SA, p. 464. Barcelona, España. 1999.
[19] H. Christiaans. "Creativity in design". PhD Thesis, Delft University of Technology, Delft, The Netherlands. 1992.

[20] H. Mintzberg. "Managing the form, function and fit to design". Ed. Design Management Journal. Vol. 2 No 3. 1991.

[21] J. Briede. "La Metodología Sistémica y el Rol del Boceto en el Diseño Conceptual de Productos Industriales". Tesis Doctoral no publicada. Universidad Politécnica de Valencia. Valencia, España. 2008. 